\title{
Prilog izradi povijesnoga atlasa samostanskoga III. reda svetoga oca Franje na hrvatskim povijesnim prostorima
}

\begin{abstract}
Na ukupno 9 karata autor prikazuje razdoblja od prvoga spomena samostanskoga III. reda svetoga oca Franje na hrvatskim prostorima sredinom 13. stoljeća, pa sve do današnjih samostana i župa, o kojima se brine Hrvatska provincija franjevaca trećoredaca glagoljaša. Karte su izrađene na osnovi postojećih historiografskih spoznaja, temeljenih na monografijama o. fra Stjepana Marije Ivančića (1852. - 1925.) pod naslovom Povjestne crte o samostanskom III Redu sv. O. Franje po Dalmaciji, Kvarneru i Istri i poraba glagoljice u istoj redodržavi. Sa prilozima (1910.) te fra Petra Runje (1938. - 2014.): Prema izvorima (1990.) i Prema izvorima II. (2012.), kao i na drugim znanstvenim i stručnim radovima.
\end{abstract}

Kao prilog svojoj knjizi Prema izvorima (1990.), fra Petar Runje priredio je povijesnu kartu samostana i spominjanja franjevaca trećoredaca na hrvatskim povijesnim prostorima. Budući da je u međuvremenu objavljeno nekoliko znanstvenih radova o hrvatskim franjevcima trećorecima s novim podacima, među kojima se nalazi i nezaobilazna fra Petrova monografija Prema izvorima II. (2012.), pojavila se potreba izrade novoga povijesnoga atlasa, na kojemu će se jasnije predstaviti prostorna rasprostranjenost zajednice franjevaca trećoredaca glagoljaša te dinamika povijesne mijene njihove prostorne prisutnosti na hrvatskim povijesnim prostorima. Stoga će se na osnovi postojećih historiografskih spoznaja, temeljenih na monografijama o. fra Stjepana Marije Ivančića (1852. - 1925.) pod naslovom Povjestne crte o samostanskom III Redu sv. O. Franje po Dalmaciji, Kvarneru i Istri i poraba glagoljice u istoj redodržavi. Sa prilozima (1910.) te fra Petra Runje (1938. - 2014.): Prema izvorima (1990.) i Prema izvorima II. (2012.), kao i na drugim znanstvenim i stručnim radovima, prikazati prostorna prisutnost franjevaca trećoredaca nizom povijesnih karata. $\mathrm{Na}$ ukupno 9 karata prikazana su razdoblja od prvoga spomena samostanskoga III. reda svetoga oca Franje na hrvatskim prostorima sredinom 13. stoljeća, pa sve do današnjih samostana i župa, o kojima se brine Hrvatska provincija franjevaca trećoredaca glagoljaša. 


\section{Popis karata:}

Karta 1. Prisutnost franjevaca trećoredaca u 13. stoljeću Karta 2. Prisutnost franjevaca trećoredaca u 14. stoljeću Karta 3. Prisutnost franjevaca trećoredaca u 15. stoljeću Karta 4. Prisutnost franjevaca trećoredaca u 16. stoljeću Karta 5. Prisutnost franjevaca trećoredaca u 17. stoljeću Karta 6. Prisutnost franjevaca trećoredaca u 18. stoljeću Karta 7. Prisutnost franjevaca trećoredaca u 19. stoljeću Karta 8. Prisutnost franjevaca trećoredaca u 20. stoljeću Karta 9. Prisutnost franjevaca trećoredaca u 21. stoljeću 


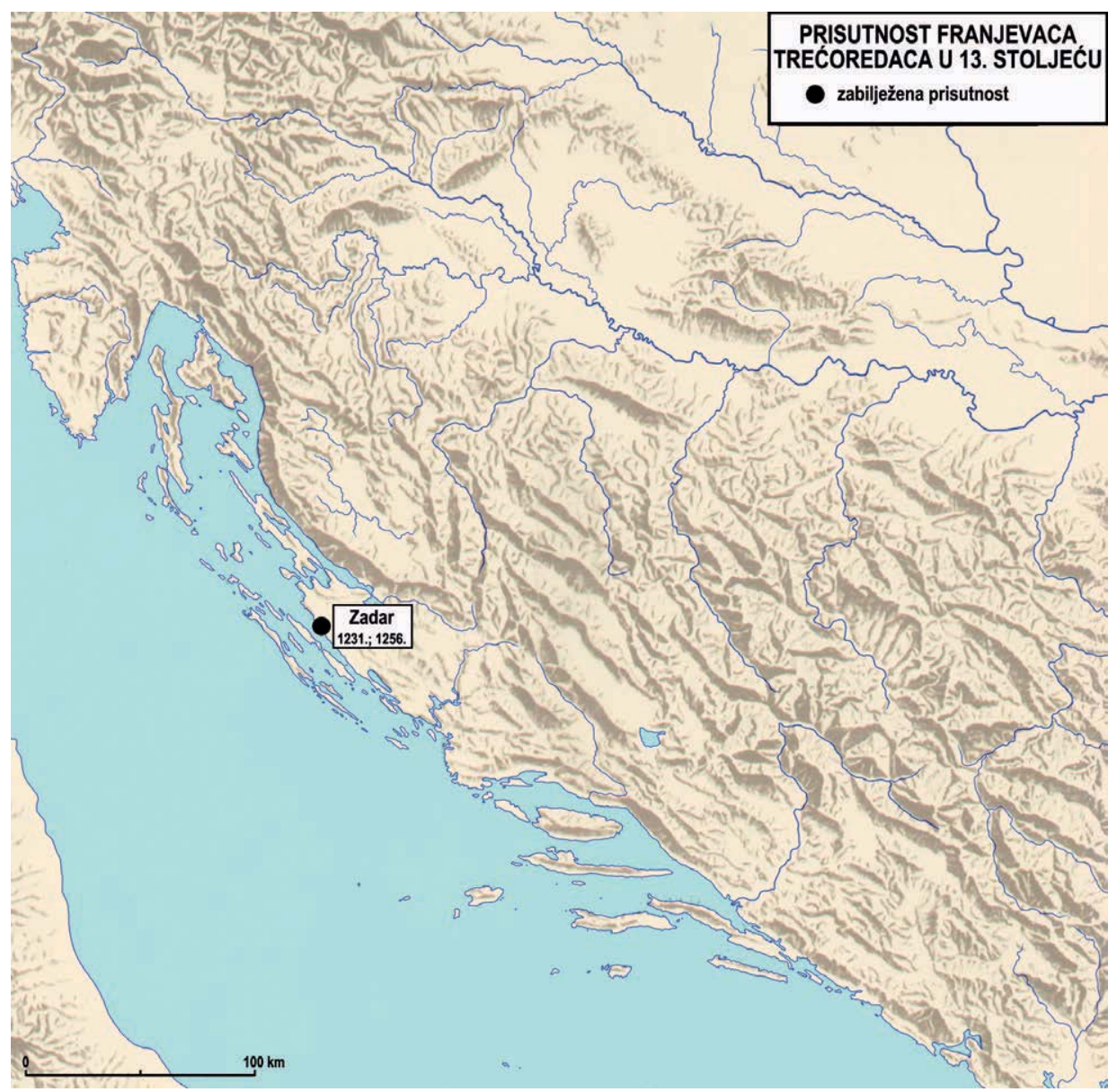

1. Prisutnost franjevaca trećoredaca u 13. stoljeću 


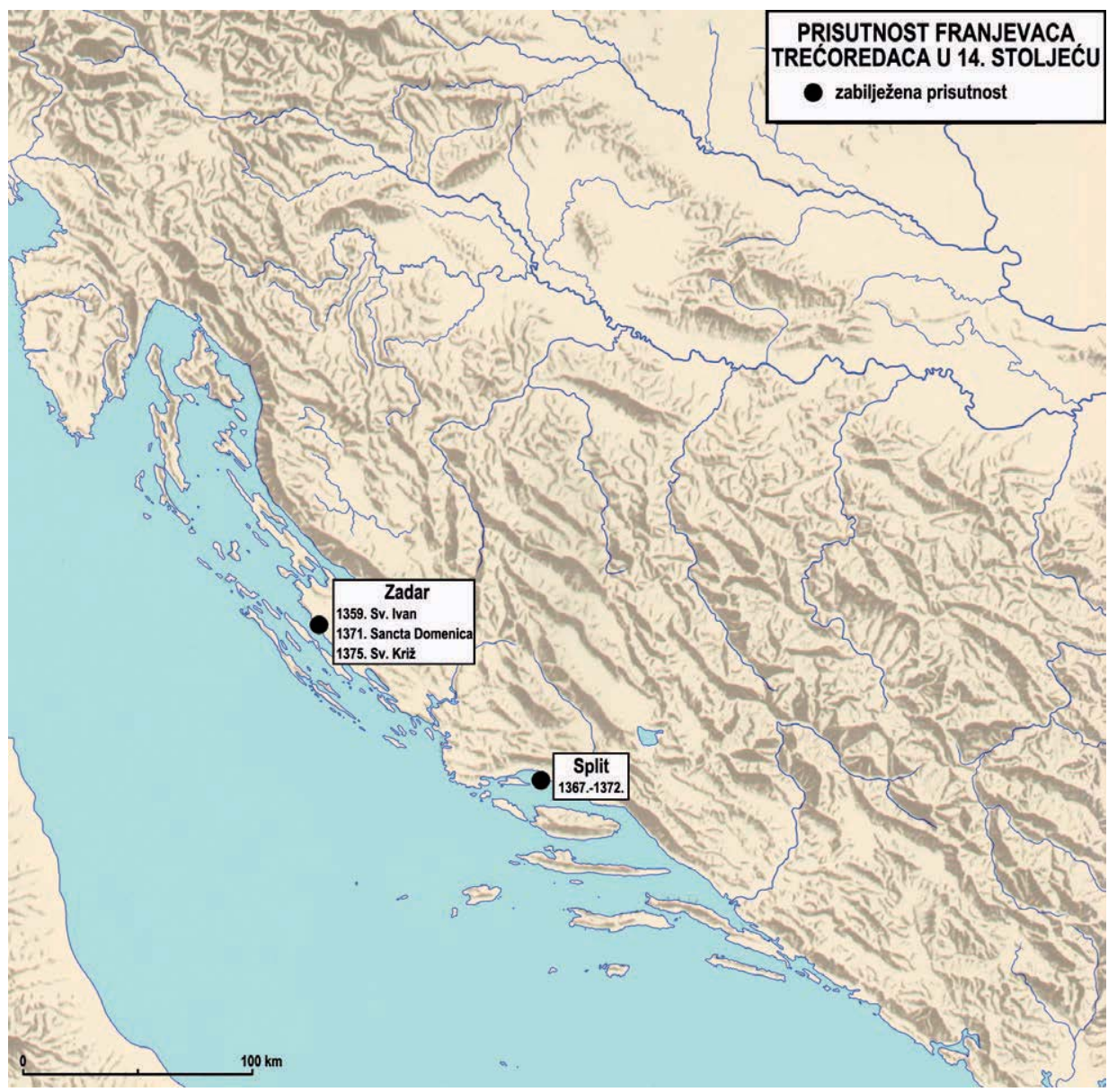

2. Prisutnost franjevaca trećoredaca u 14. stoljeću 
Hrvoje Kekez - Prilog izradi povijesnoga atlasa samostanskoga III. reda svetoga oca Franje...

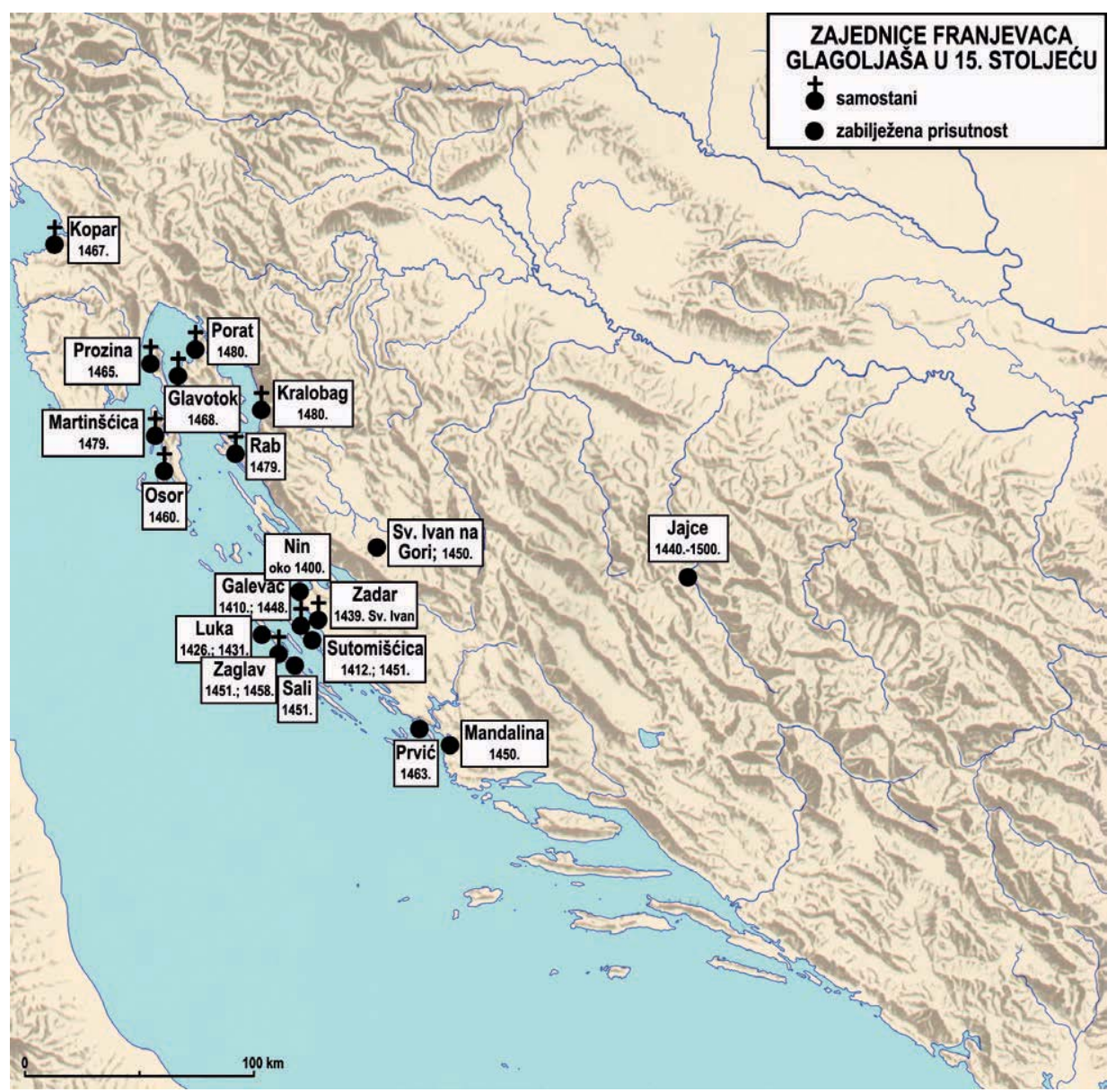

3. Prisutnost franjevaca trećoredaca u 15. stoljeću 


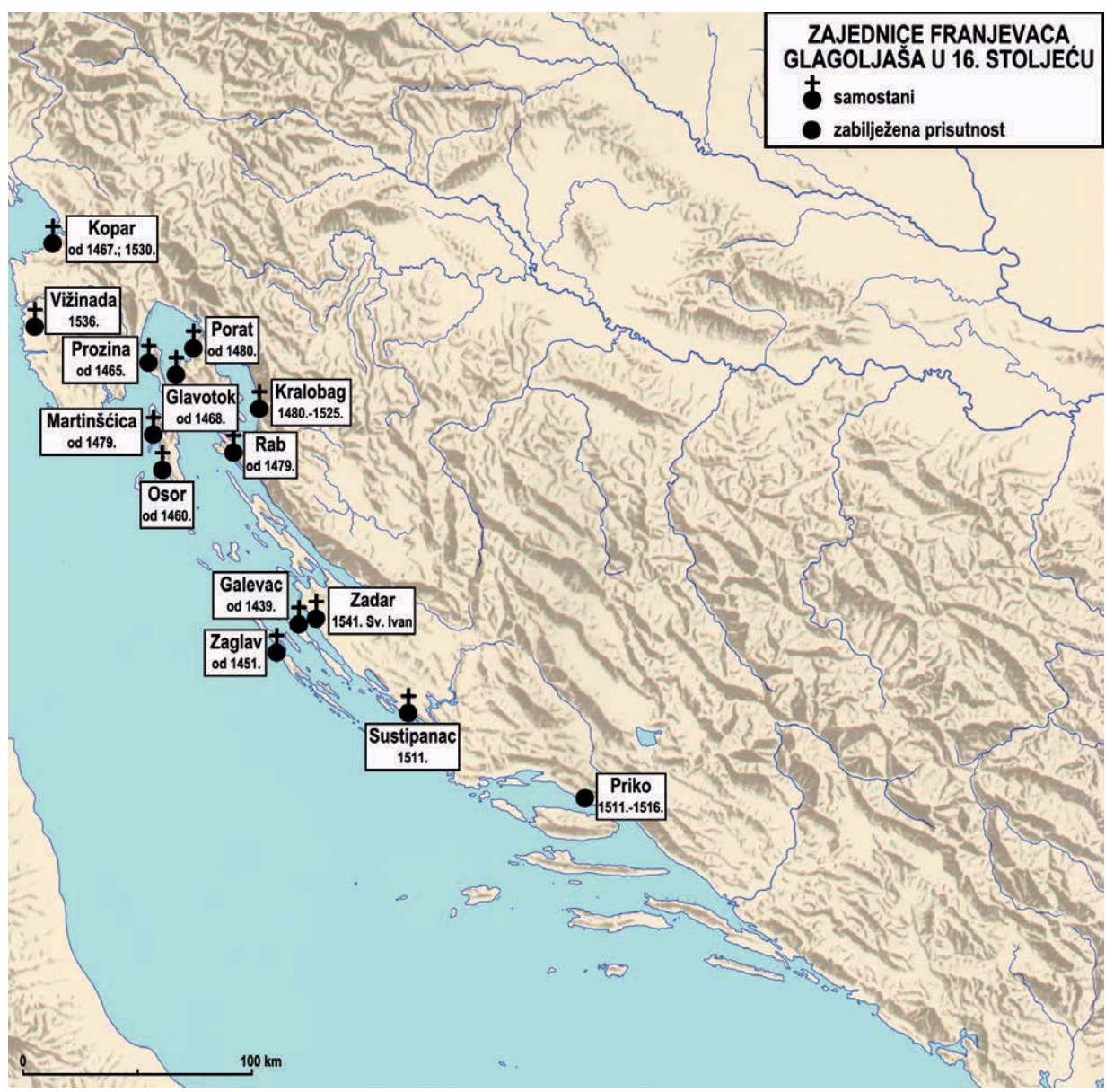

4. Prisutnost franjevaca trećoredaca u 16. stoljeću 
Hrvoje Kekez - Prilog izradi povijesnoga atlasa samostanskoga III. reda svetoga oca Franje...

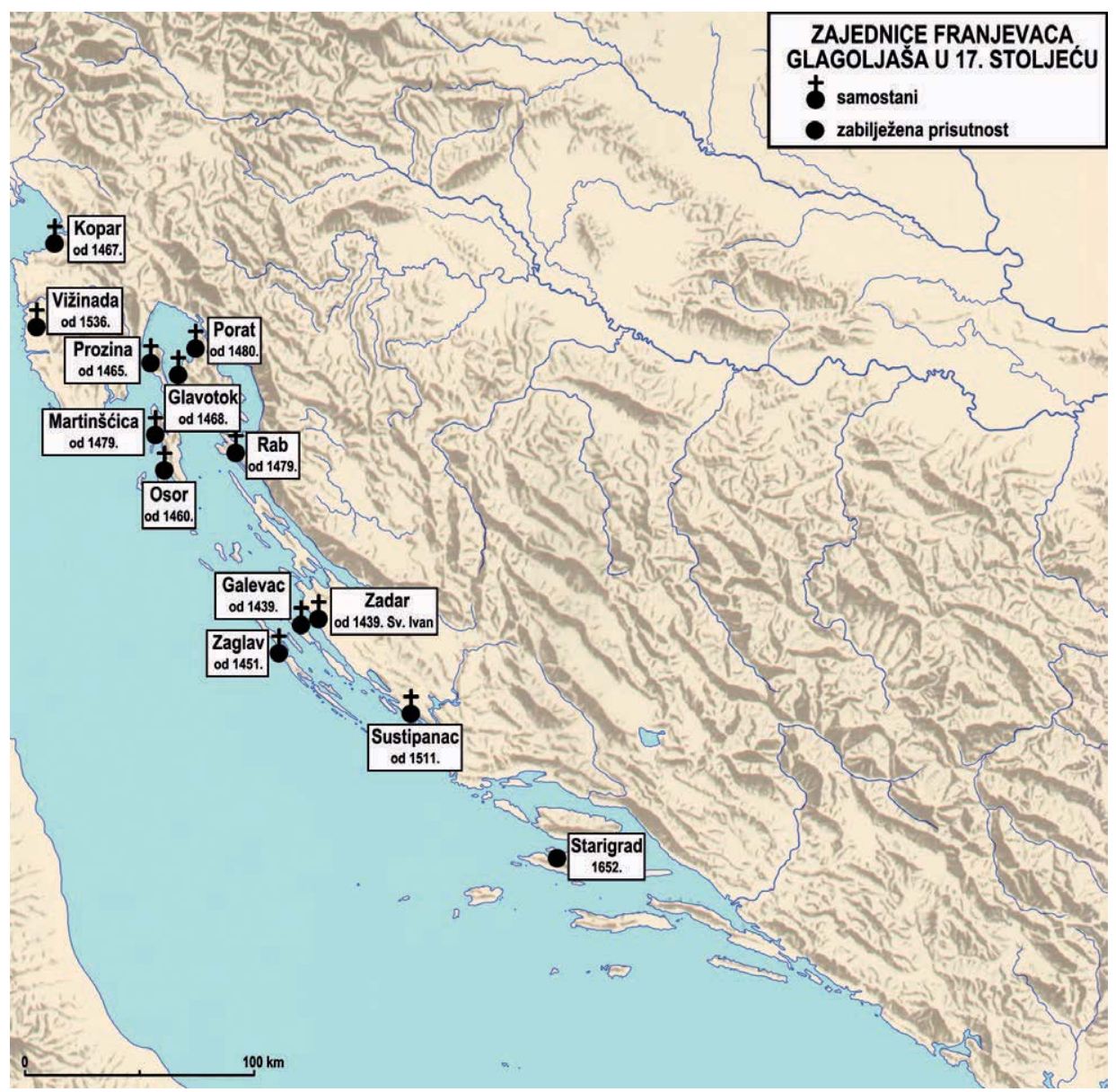

5. Prisutnost franjevaca trećoredaca u 17. stoljeću 


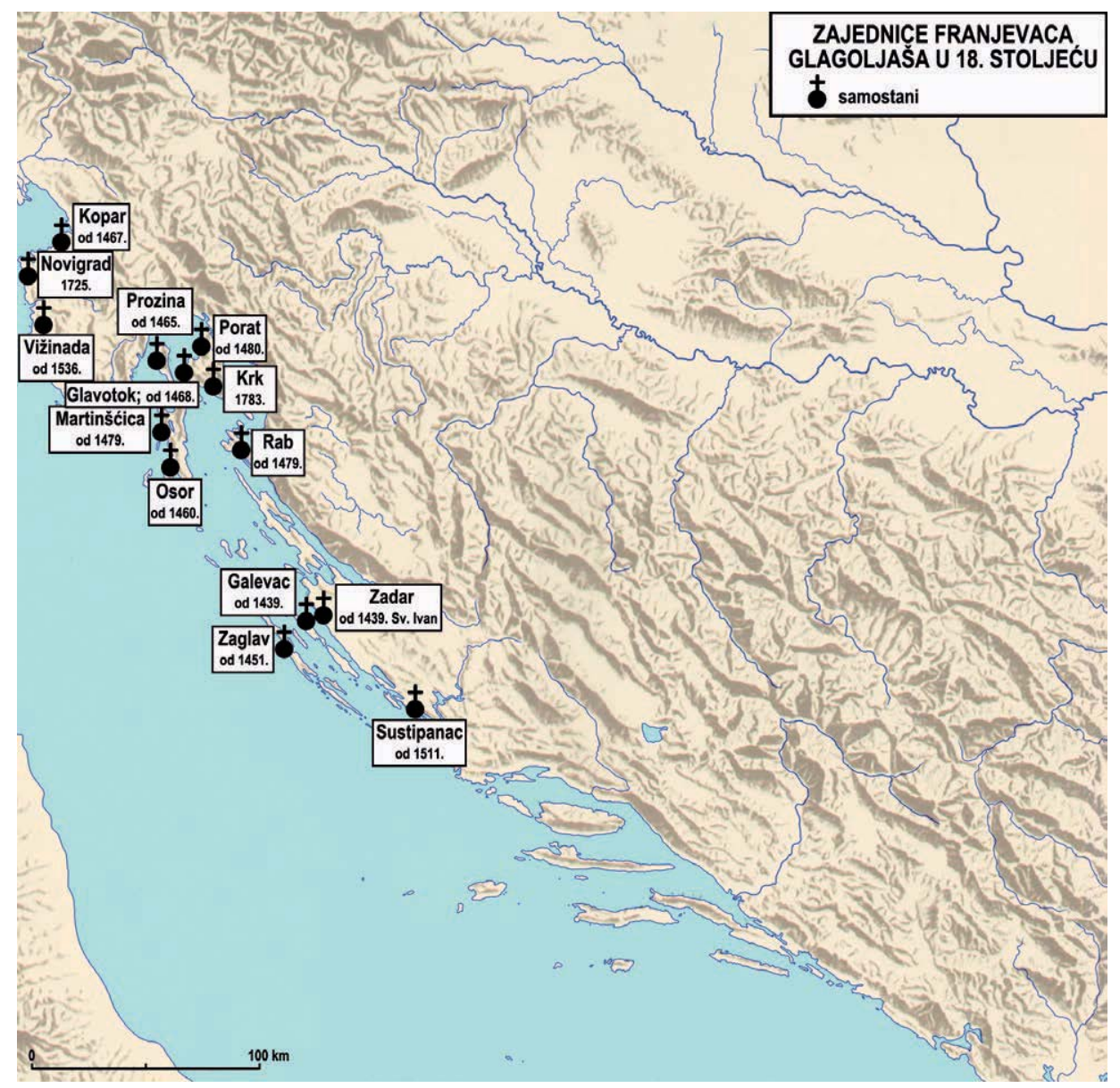

6. Prisutnost franjevaca trećoredaca u 18. stoljeću 
Hrvoje Kekez - Prilog izradi povijesnoga atlasa samostanskoga III. reda svetoga oca Franje...

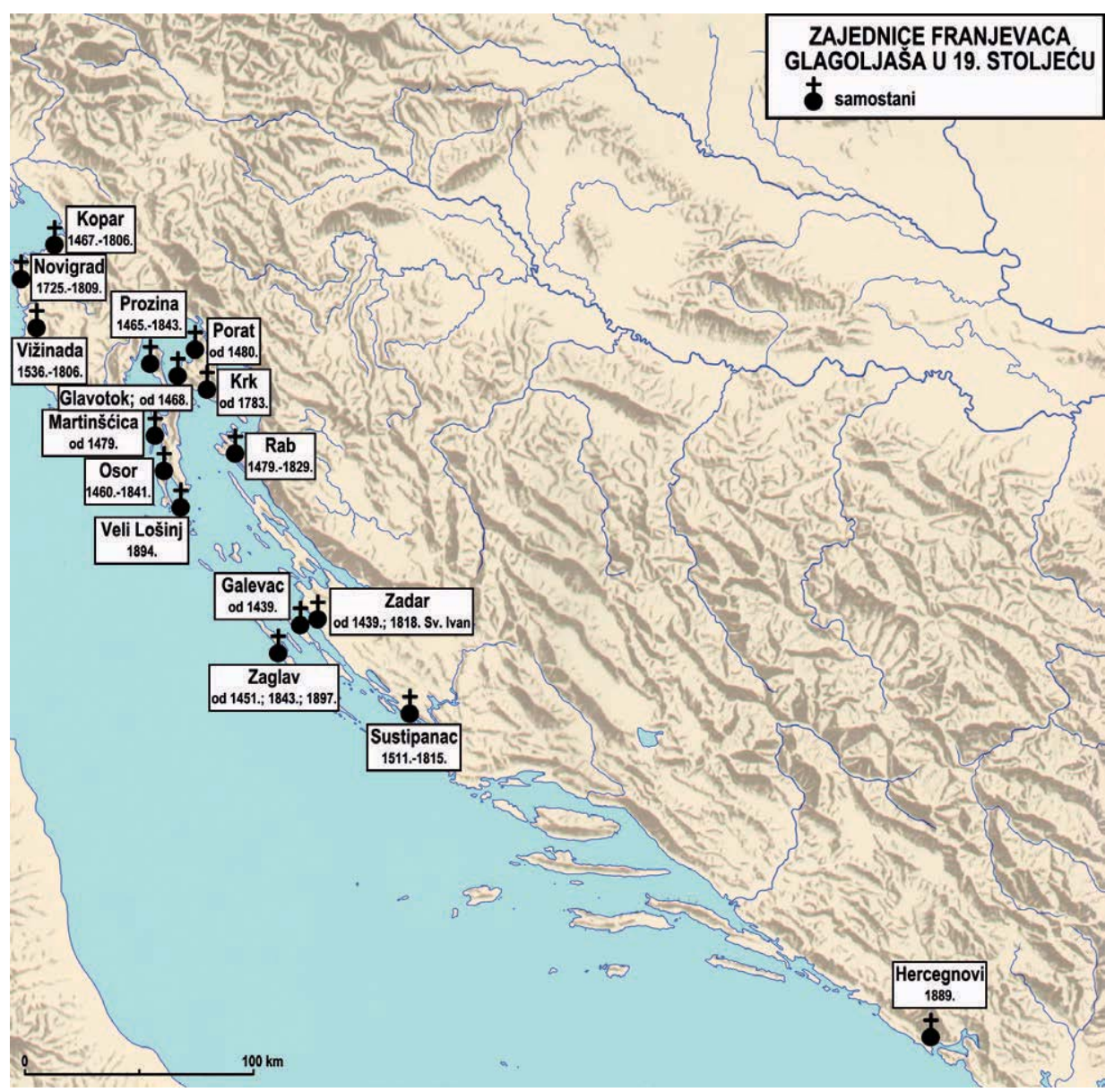

7. Prisutnost franjevaca trécoredaca u 19. stoljeću 


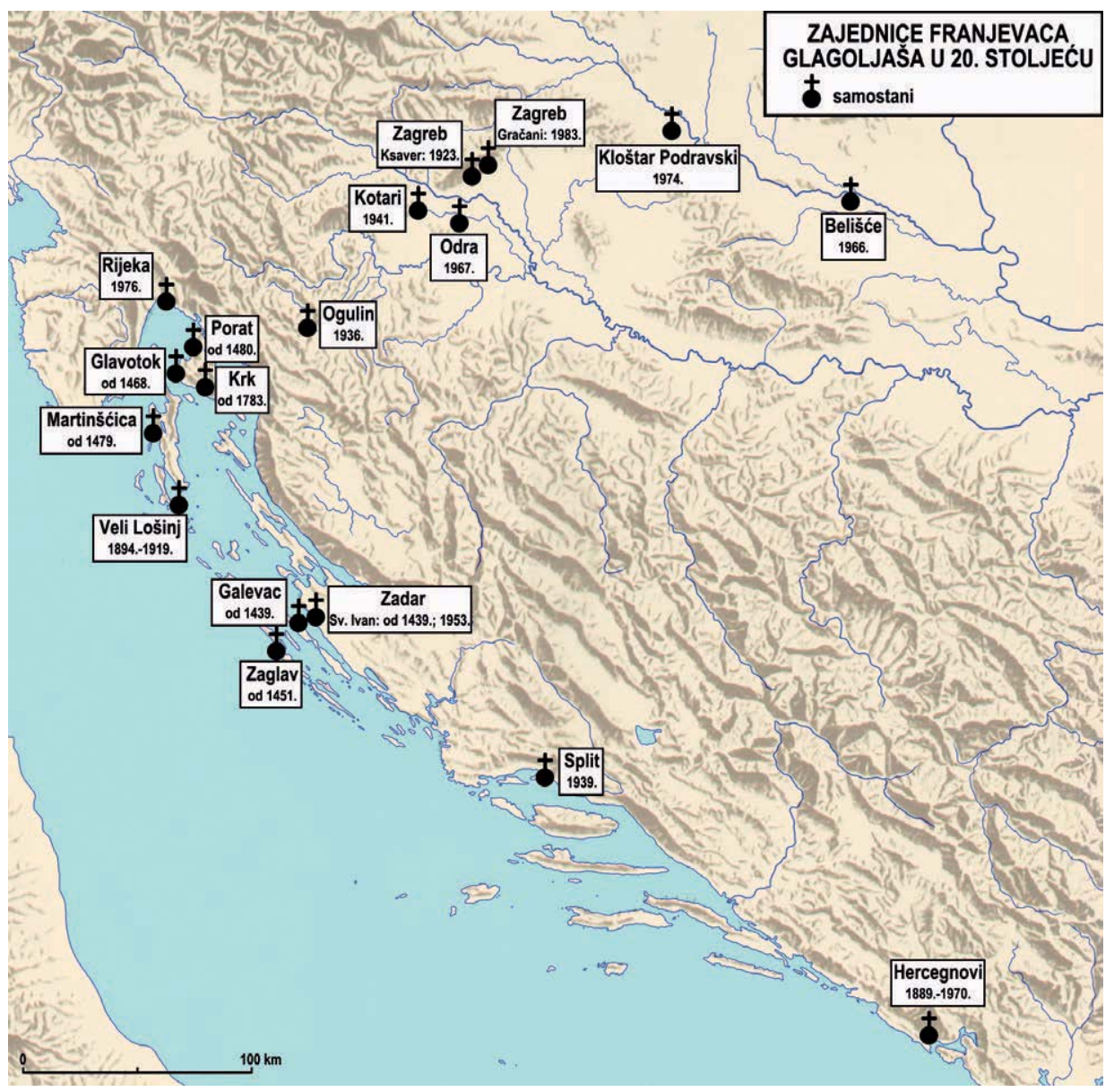

8. Prisutnost franjevaca trećoredaca u 20. stoljeću 
Hrvoje Kekez - Prilog izradi povijesnoga atlasa samostanskoga III. reda svetoga oca Franje...

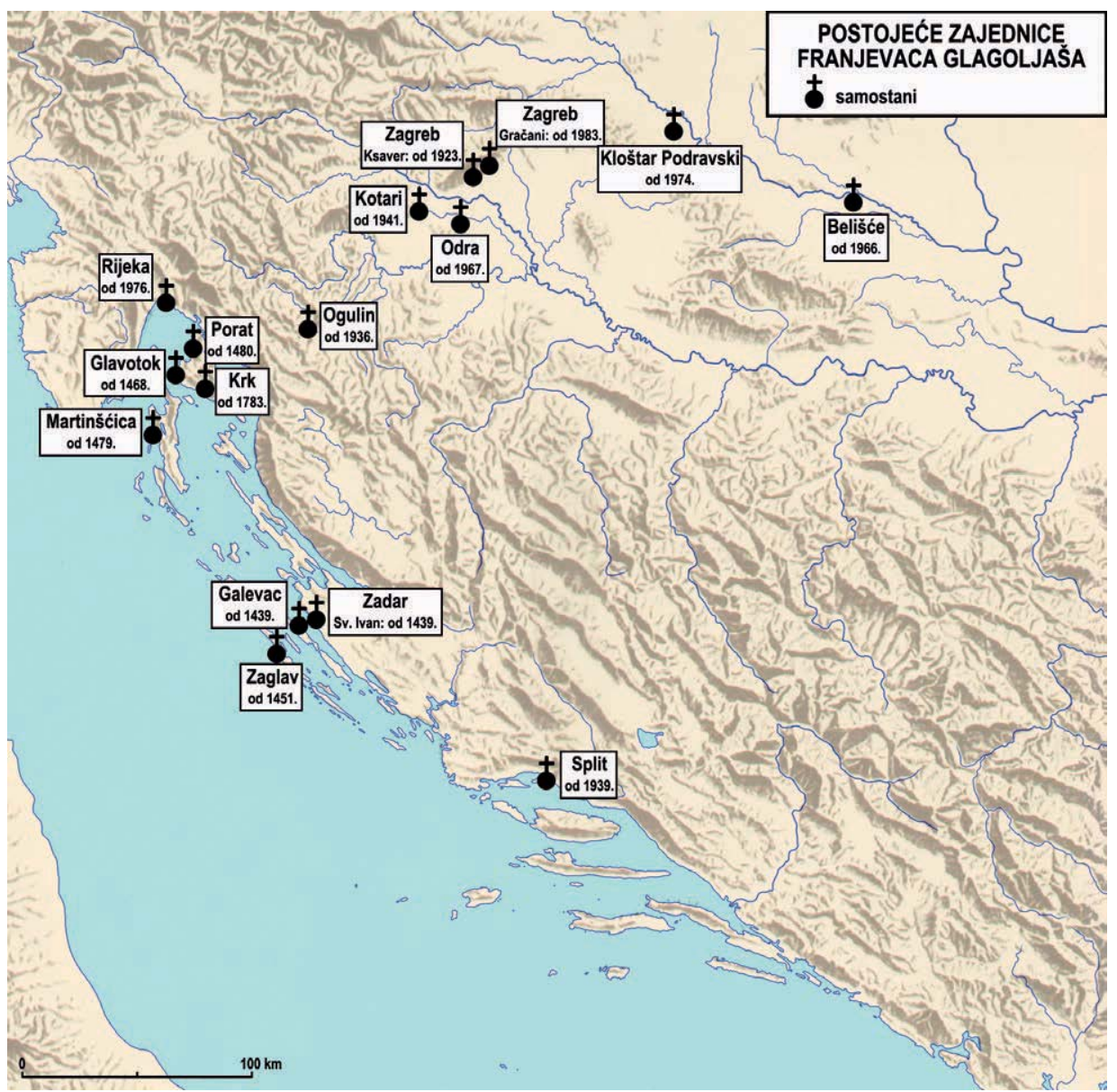

9. Prisutnost franjevaca trećoredaca u 21. stoljeću 


\section{Bibliografija}

IVANČIĆ, Stjepan Nauč. (prir.). 1910. Povjestne crte o samostanskom III Redu sv. O. Franje po Dalmaciji, Kvarneru i Istri i poraba glagoljice u istoj redodržavi. Sa prilozima. Zadar: Odlikovana tiskarna E. Vitaliani.

RUNJE, Petar. 1990. Prema izvorima [Novaja i vethaja 2]. Zagreb: Provincijalat franjevaca trećoredaca.

RUNJE, Petar. 2012. Prema izvorima II. Rasprave i članci o hrvatskim franjevcima trećoredcima glagoljašima. Ur. Tomislav Galović [Novaja i vethaja 9; Krčki zbornik 68, Posebno izdanje 61]. Krk-Zagreb: Povijesno društvo otoka Krka, Provincijalat franjevaca trećoredaca.

\section{A Contribution to the Creation of a Historical Atlas of The Monastic III Order of Holy Father Francis in Croatian Historical Lands}

As an appendix to his book Prema izvorima (1990) friar Petar Runje composed a historical map of tertiary Franciscan monasteries and written records in the Croatian historical lands. Since several scientific papers on the Croatian Franciscan tertiaries as well as an indispensable second part of the said book from the same author (Prema izvorima II, 2012) have been published since that time, a need was felt to create a new historical atlas to present more clearly the spatial distribution of tertiary communities and the dynamics of the historical changes in the spatial presence of the Franciscans of the Third order in Croatian lands. Therefore, based on existing historiographic knowledge drawn from the monographs from father friar Stjepan Marija Ivančić (1852 - 1925) and friar Petar Runje (1938 - 2014) as well as from scientific papers published so far, we propose to portray the spatial presence of tertiary Franciscans in a series of historical maps. The periods from the earliest mention of tertiary Franciscans in the Croatian lands in the middle of the $13^{\text {th }}$ century up to the modern-day monasteries and parishes administered by the Croatian Province of Glagolitic Franciscan Tertiaries will be shown on a total of 9 maps.

Keywords: Historical Atlas, The Monastic III Order of Holy Father Francis, Croatian Historical Lands, Stjepan Marija Ivančić (1852 - 1925), Petar Runje (1938 - 2014)

Ključne riječi: povijesni atlas, samostanski III. red svetoga oca Franje, hrvatski povijesni prostori, Stjepan Marija Ivančić (1852. - 1925.), Petar Runje (1938. - 2014.)

Hrvoje Kekez

Hrvatsko katoličko sveučilište

HR-10000 Zagreb, Ilica 242 hrvoje.kekez@unicath.hr 


\section{FILOZOFSKI FAKULTET SVEUČILIŠTA U ZAGREBU \\ ZAVOD ZA HRVATSKU POVIJEST \\ INSTITUTE OF CROATIAN HISTORY \\ INSTITUT FÜR KROATISCHE GESCHICHTE}
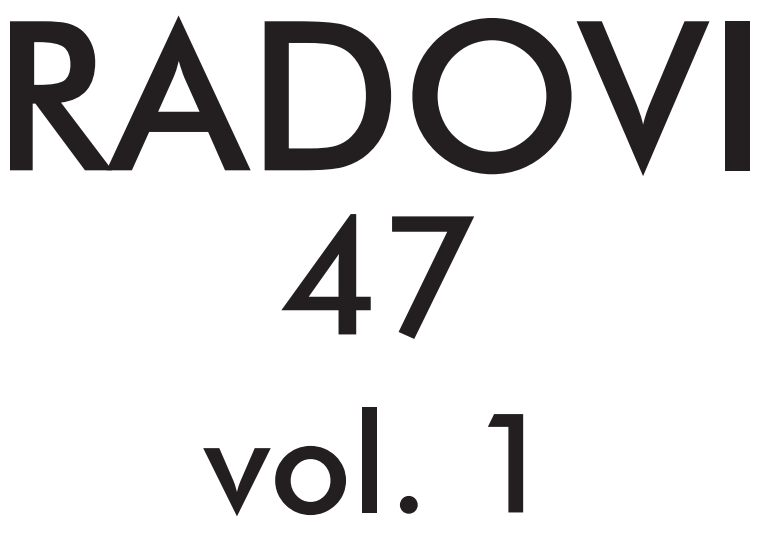

ZAVOD ZA HRVATSKU POVIJEST

FILOZOFSKOGA FAKULTETA SVEUČILIŠTA U ZAGREBU

\section{PF press \\ ZAGREB 2015.}




\title{
RADOVI ZAVODA ZA HRVATSKU POVIJEST FILOZOFSKOGA FAKULTETA SVEUČILIŠTA U ZAGREBU
}

\author{
Knjiga 47, vol. 1
}

\author{
Izdavač / Publisher \\ Zavod za hrvatsku povijest \\ Filozofskoga fakulteta Sveučilišta u Zagrebu \\ FF-press \\ Za izdavača / For Publisher \\ Vlatko Previšić \\ Glavni urednik / Editor-in-Chief \\ Hrvoje Gračanin \\ Izvršna urednica / Executive Editor \\ Inga Vilogorac Brčić \\ Uredništvo / Editorial Board
}

Bruna Kuntić-Makvić (stara povijest/ancient history), Zrinka Nikolić Jakus (srednji vijek/ medieval history), Hrvoje Petrić (rani novi vijek/early modern history), Željko Holjevac (moderna povijest/modern history), Tvrtko Jakovina (suvremena povijest/contemporary history),

Silvija Pisk (mikrohistorija i zavičajna povijest/microhistory and local history),

Zrinka Blažević (teorija i metodologija povijesti/theory and methodology of history)

Međunarodno uredničko vijeće / International Editorial Council

Denis Alimov (Sankt Peterburg), Živko Andrijašević (Nikšić), Csaba Békés (Budapest), Rajko Bratož (Ljubljana), Snježana Buzov (Columbus, Ohio), Svetlozar Eldarov (Sofija), Toni Filiposki (Skopje), Aleksandar Fotić (Beograd), Vladan Gavrilović (Novi Sad), Alojz Ivanišević (Wien),

Egidio Ivetić (Padova), Husnija Kamberović (Sarajevo), Karl Kaser (Graz),

Irina Ognyanova (Sofija), Géza Pálffy (Budapest), Ioan-Aurel Pop (Cluj),

Nade Proeva (Skopje), Alexios Savvides (Kalamata), Vlada Stanković (Beograd), Ludwig Steindorff (Kiel), Peter Štih (Ljubljana)

Izvršna urednica za tuzemnu i inozemnu razmjenu / Executive Editor for Publications Exchange Kristina Milković

Tajnik uredništva / Editorial Board Assistant

Dejan Zadro

Adresa uredništva/Editorial Board address

Zavod za hrvatsku povijest, Filozofski fakultet Zagreb, Ivana Lučića 3, HR-10 000, Zagreb

Tel. ++385 (0)1 6120 150, 6120 158, faks ++385 (0)1 6156879

Časopis izlazi jedanput godišnje / The Journal is published once a year

Časopis je u digitalnom obliku dostupan na / The Journal in digital form is accessible at Portal znanstvenih časopisa Republike Hrvatske „Hrčak“ http://hrcak.srce.hr/radovi-zhp

Financijska potpora za tisak časopisa / The Journal is published with the support by

Ministarstvo znanosti, obrazovanja i športa Republike Hrvatske

Časopis je indeksiran u sljedećim bazama / The Journal is indexed in the following databases:

Directory of Open Access Journals, EBSCO, SCOPUS, ERIH PLUS 
Naslovna stranica

Iva Mandić

Grafičko oblikovanje i računalni slog

Marko Maraković

Lektura

Samanta Paronić

Tisak

Web2tisak, Zagreb

Naklada

250 primjeraka

Časopis je u digitalnom obliku dostupan na Portalu znanstvenih časopisa Republike Hrvatske ,Hrčak“ http://hrcak.srce.hr/radovi-zhp

The Journal is accessible in digital form at the Hrcak - Portal of scientific journals of Croatia http://hrcak.srce.hr/radovi-zhp 


\section{RADOVI 47}

\section{vol. 1}

ZaVoda za hrVAtSku poviJest FILOZOFskoga fakulteta SVeuČILIŠTA u Zagrebu 


\title{
Tematski blok / Themed issue
}

\section{TREĆOREDSKA GLAGOLJAŠKA TRADICIJA U EUROPSKOM KONTEKSTU TERTIARY GLAGOLITIC TRADITION IN EUROPEAN CONTEXT}

\author{
Radovi međunarodnoga znanstvenog skupa \\ održanoga 27. i 28. IX. 2013. na Hrvatskom katoličkom sveučilištu u Zagrebu \\ u organizaciji \\ Provincije franjevaca trećoredaca glagoljaša u Zagrebu, Hrvatskoga katoličkog \\ sveučilišta u Zagrebu, Filozofskoga fakulteta Sveučilišta u Zagrebu - Odsjek za \\ povijest, Filozofskoga fakulteta Sveučilišta u Splitu - Odsjek za povijest, Instituta \\ za povijest umjetnosti u Zagrebu i Staroslavenskoga instituta u Zagrebu \\ Proceedings of the International Scientific Conference \\ held on 27th and 28th September 2013 at the Catholic University of Croatia in Zagreb \\ and organized by \\ the Province of the Glagolitic Friars of the Third Order Regular, Catholic University \\ of Croatia in Zagreb, Faculty of Humanities and Social Sciences of the University \\ of Zagreb - Department of History, Faculty of Humanities and Social Sciences of \\ the University of Split - Department of History, Institute of Art History, \\ and Old Church Slavonic Institute
}

Gosti urednici / Guest editors

\author{
Ivan BOTICA \\ Tomislav GALOVIĆ \\ Kristijan KUHAR
}

